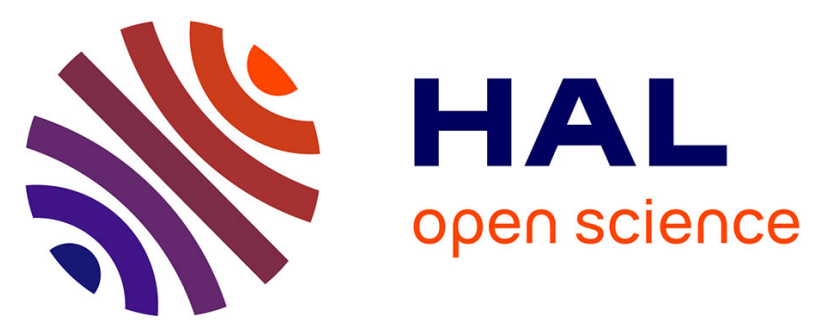

\title{
Facile synthesis and strong antiproliferative activity of disubstituted diphenylmethylidenyl-[3]ferrocenophanes on breast and prostate cancer cell lines
}

Meral Görmen, Pascal Pigeon, Siden Top, Anne Vessières, Marie-Aude Plamont, Elisabeth A. Hillard, Gérard Jaouen

\section{To cite this version:}

Meral Görmen, Pascal Pigeon, Siden Top, Anne Vessières, Marie-Aude Plamont, et al.. Facile synthesis and strong antiproliferative activity of disubstituted diphenylmethylidenyl-[3]ferrocenophanes on breast and prostate cancer cell lines. MedChemComm, 2010, 1 (2), pp.149-151. 10.1039/c0md00026d . hal-01230393

\section{HAL Id: hal-01230393 \\ https://hal.science/hal-01230393}

Submitted on 17 Mar 2016

HAL is a multi-disciplinary open access archive for the deposit and dissemination of scientific research documents, whether they are published or not. The documents may come from teaching and research institutions in France or abroad, or from public or private research centers.
L'archive ouverte pluridisciplinaire HAL, est destinée au dépôt et à la diffusion de documents scientifiques de niveau recherche, publiés ou non, émanant des établissements d'enseignement et de recherche français ou étrangers, des laboratoires publics ou privés. 


\section{Facile synthesis and strong antiproliferative activity of disubstituted diphenylmethylidenyl-[3]ferrocenophanes on breast and prostate cancer cell lines}

Meral Gormen, Pascal Pigeon, Siden Top*, Anne Vessières, Marie-Aude Plamont, Elizabeth A. Hillard, Gérard Jaouen

DOI: $10.1039 / \mathrm{c} 0 \mathrm{md} 00026 \mathrm{~d}$

Some new derivatives of 1 -[di-(4- $R$-phenyl)-methylidenyl)]-[3]ferrocenophane where $\mathbf{R}=$ $\mathrm{OH}, \mathrm{NH}_{2}, \mathrm{NHCOCH}_{3}$ and the phenyl substitution is mixed or identical, are highly antiproliferative against MDA-MB-231 and $\mathrm{PC} 3$ cancer cells, with $\mathrm{IC}_{50}$ values ranging from 0.05-17.6 $\mu \mathrm{M}$ on MDA-MB-231 and 0.02-12.5 $\mu \mathrm{M}$ on PC3.

As part of our study on the antiproliferative effects of compounds based on the ferrocenyl-diphenyl-butadiene skeleton, we have recently shown that [3]ferrocenophane is an attractive pharmacophore in the development of antiproliferative agents for hormonerefractory breast cancer cells. ${ }^{1,2}$ For the series of compounds based on the 1-[(4-R-phenyl)phenyl-methylidenyl]-[3]ferrocenophane skeleton, where $R=\mathrm{OH}$ (1), $\mathrm{NH}_{2}$ (2) and $\mathrm{NHCOCH}_{3}(3)$, the incorporation of the rigid [3] ferrocenophane moiety resulted in up to a four-fold increase in activity compared to the corresponding ferrocene series, with $\mathrm{IC}_{50}$ values of 0.2 to $0.5 \mu \mathrm{M}$ on ER- breast cancer cells, (chart 1 ). ${ }^{2}$ The cytotoxicity of such molecules seemed to be further enhanced by substitution on both of the phenyl rings; for example, the 4,4'-bis-hydroxy compound 4 gave an $\mathrm{IC}_{50}$ value of $0.09 \mu \mathrm{M}$ on MDA-MB-231, compared to $0.47 \mu \mathrm{M}$ for the monosubstituted 4-hydroxy analogue 1 (chart 1). ${ }^{1}$ These two observations together suggest that a combination of a $\mathrm{NH}_{2}, \mathrm{NHCOCH}_{3}$, and $\mathrm{OH}$ moieties on each of the phenyl rings should give access to the most active molecules yet. We therefore here report the synthesis and characterization of the unsubstituted compound 5 and compounds 6-9, possessing mixed or identical bis-substitution, and their in vitro antiproliferative effects against hormone-independent breast (MDA-MB-231) and prostate (PC3) cancer cell lines.

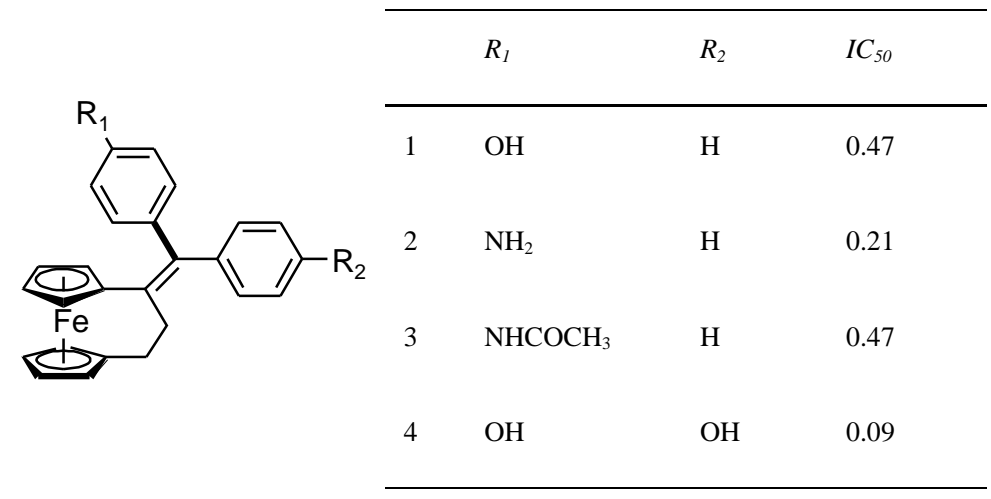

Chart 1. Previously reported compounds and their $\mathrm{IC}_{50}$ values $(\mu \mathrm{M})$ against MDA-MB-231 hormone-independent breast cancer cells.

Compounds 5, 6 and 7 were obtained by a McMurry cross coupling reaction between [3]ferrocenophane-1-one ${ }^{3}$ and the appropriate benzophenone (scheme 1a). ${ }^{2}$ As a precursor to $\mathbf{6}$, 4-nitro-4'-hydroxy benzophenone was synthesized in $46 \%$ overall yield via a Friedel Crafts acylation of anisole with $p$-nitrobenzoyl chloride followed by a deprotection of the $\mathrm{OMe}$ group with $\mathrm{HBr}$ in acetic acid. ${ }^{4,5}$ The nitro-substituted compound was used because 1) the 
Friedel Crafts reaction step is not compatible with amino substitution, and 2) the in situ reduction of $\mathrm{NO}_{2}$ to $\mathrm{NH}_{2}$ under McMurry conditions is well known. ${ }^{6}$ McMurry himself recognized this type of reduction, and noted that it could be avoided by conducting the reaction at low temperature. ${ }^{7}$ Concerning the low yield of $\mathbf{6}$, it has been reported that this type of coupling is decelerated by the presence of an amino group. ${ }^{8}$ Compound $\mathbf{8}$ was subsequently obtained in $63 \%$ yield from the selective acetylation of $\mathbf{6}$ in presence of pyridine in THF (scheme 1b).

As a precursor for 7, 4,4'-bisacetylamino benzophenone was synthesized in $88 \%$ yield by acetylation of commercially available $4,4^{\prime}$ '-bisaminobenzophenone with acetyl chloride. ${ }^{9}$ Compound 9 was obtained in $78 \%$ yield by deacetylation of 7 in the presence of $\mathrm{HCl}$ in $\mathrm{EtOH}$ (scheme 1c). Direct McMurry cross coupling with 4,4'-diaminobenzophenone was not successful, yielding only the ferrocenyl homo-coupled product and unreacted benzophenone.

a

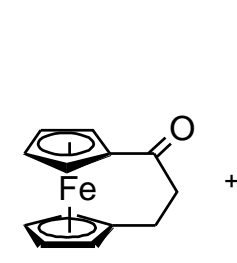

$+$

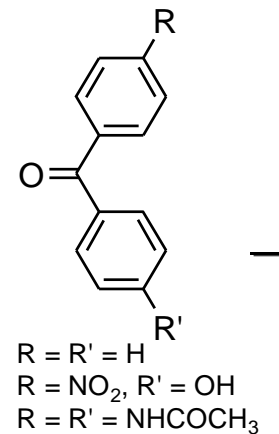

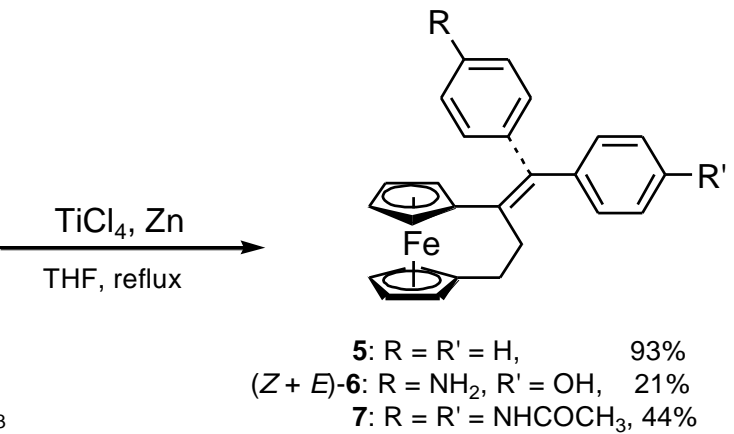

7: $\mathrm{R}=\mathrm{R}^{\prime}=\mathrm{NHCOCH}_{3}, 44 \%$

b
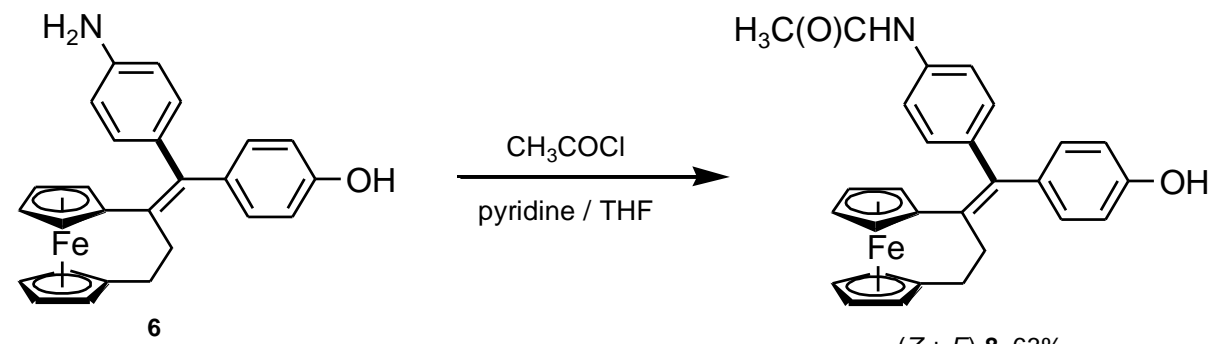

$(Z+E)-8,63 \%$
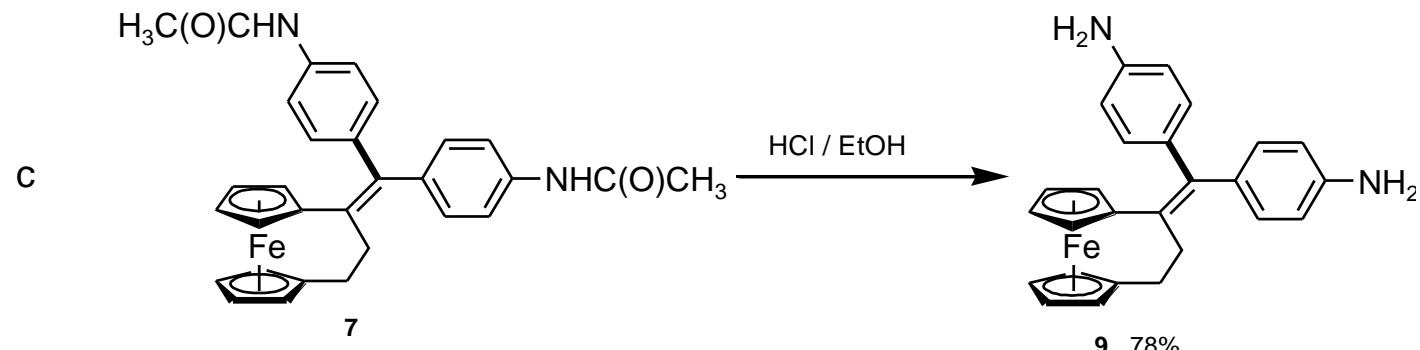

9, $78 \%$

Scheme 1

Crystals of $\mathbf{5}$ and Z-8 suitable for X-ray structure analysis were obtained from hexanes and acetonitrile solutions, respectively. Compound $\mathbf{5}$ crystallized in an orthorhombic space group, while $\mathbf{8}$ crystallized in a monoclinic space group with one molecule of $Z-\mathbf{8}$ and one molecule of acetonitrile per asymmetric unit (figure 1). ${ }^{10}{ }^{1} \mathrm{H}$ NMR analysis of the crystals showed the presence of one isomer; the chemical shifts corresponded to the minor isomer in the mixture obtained after HPLC purification. 

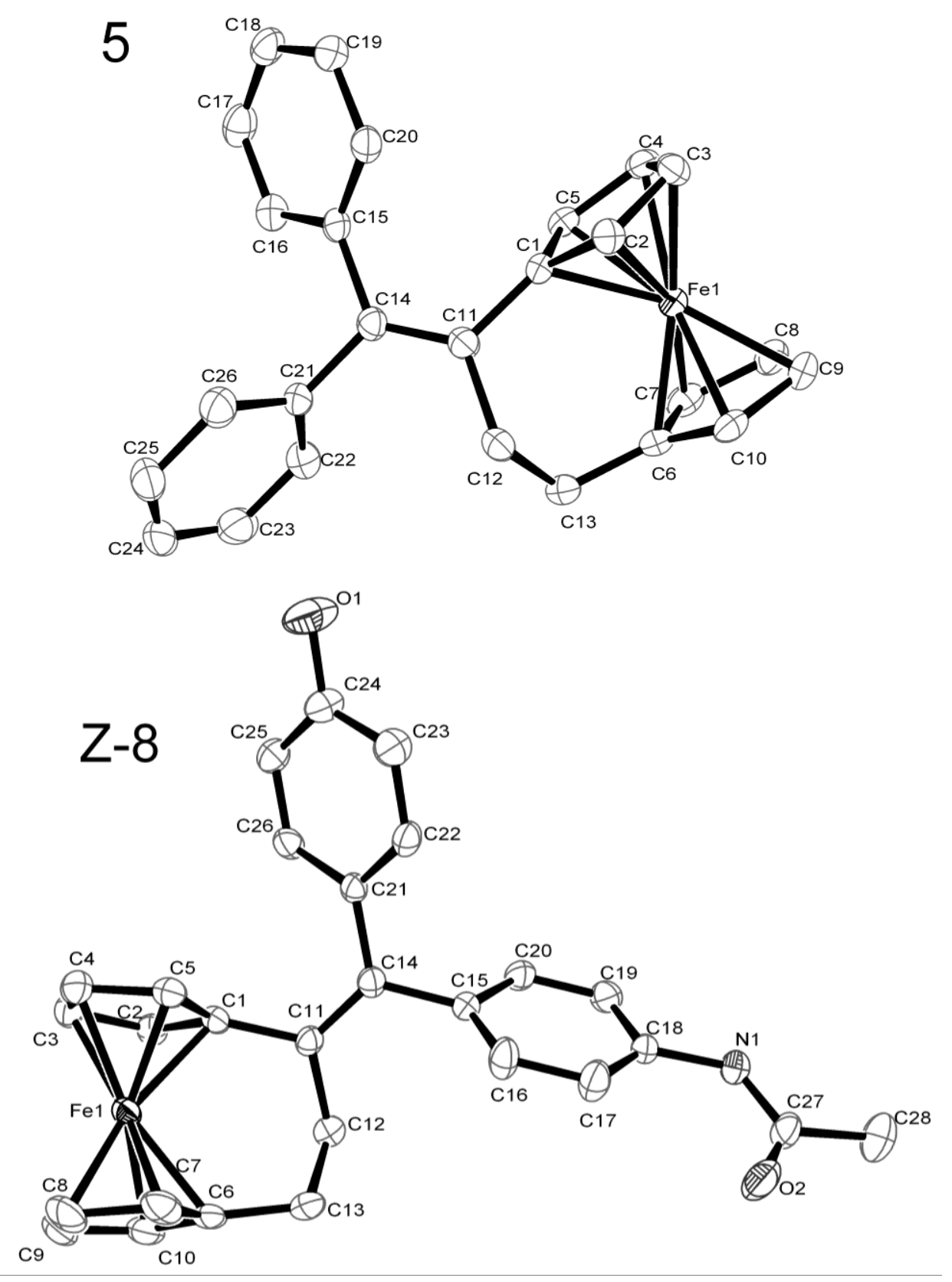

Figure 1. ORTEP diagrams of 5 and Z-8. Thermal ellipsoids shown at 50\% probability. Hydrogen atoms and acetonitrile molecule of solvation from the Z-8. $\mathrm{CH}_{3} \mathrm{CN}$ have been omitted from the diagrams for clarity.

The structure of the [3]ferrocenophane moiety in $\mathbf{5}$ and $\mathbf{8}$ is very similar to that reported by Erker and coworkers, with the corresponding boat-like conformation of the bridge. ${ }^{11}$ The bridge is slightly too short to connect the two $\mathrm{Cp}$ rings without distortion in the ferrocene group. The eclipsed $\eta^{5}-\mathrm{C}_{5} \mathrm{H}_{4}$ rings are therefore not coplanar, but rather tilted towards the bridge, such that the angle made by the centroids of the two $\eta^{5}-\mathrm{C}_{5} \mathrm{H}_{4}$ rings and the ferrocene is $173^{\circ}$ and the angle between the best planes of the $\eta^{5}-\mathrm{C}_{5} \mathrm{H}_{4}$ ring is approximately $10^{\circ}$. Due to this distortion, the $\mathrm{Fe}-\mathrm{C}$ distances in the $\eta^{5}-\mathrm{C}_{5} \mathrm{H}_{4}$ rings range from about 2.03 to $2.08 \AA$. The bridge itself is also slightly strained; the respective angles deviate slightly from tetrahedral and trigonal geometries. See supplementary information for selected bond distances and angles. 
All of the new compounds were tested for their anti-proliferative effects against hormone-independent MDA-MB-231 breast and PC3 prostate cancer cells (table 1).

Table 1. $\mathrm{IC}_{50}$ values on MDA-MB-231 breast cancer PC3 prostate cancer cells.

\begin{tabular}{lllll} 
& $\mathrm{R}_{1}$ & $\mathrm{R}_{2}$ & $\mathrm{IC}_{50}(\mu \mathrm{M})$ & \\
\hline & & & $\mathrm{MDA}-\mathrm{MB}-231$ & $\mathrm{PC} 3$ \\
\hline $\mathbf{5}$ & $\mathrm{H}$ & $\mathrm{H}$ & $0.92 \pm 0.11$ & $2.43 \pm 0.47$ \\
$\mathbf{4}$ & $\mathrm{OH}$ & $\mathrm{OH}$ & $0.09 \pm 0.01^{\mathrm{a}}$ & $0.14 \pm 0.01$ \\
$(E+Z)-\mathbf{6}$ & $\mathrm{NH}_{2}$ & $\mathrm{OH}$ & $0.06 \pm 0.01$ & $0.03 \pm 0.01$ \\
$\mathbf{7}$ & ${\mathrm{NHCO}-\mathrm{CH}_{3}}$ & $\mathrm{NHCO}-\mathrm{CH}_{3}$ & $5.64 \pm 1.13$ & $12.45 \pm 0.85$ \\
$(E+Z)-\mathbf{8}$ & $\mathrm{NHCO}^{-\mathrm{CH}_{3}}$ & $\mathrm{OH}$ & $0.09 \pm 0.02$ & $0.02 \pm 0.00$ \\
$\mathbf{9}$ & $\mathrm{NH}_{2}$ & $\mathrm{NH}_{2}$ & $0.05 \pm 0.01$ & $0.05 \pm 0.00$ \\
\hline
\end{tabular}

${ }^{a}$ value from ref 1 .

As predicted, the new compounds, possessing $\mathrm{OH} / \mathrm{NH}_{2}, \mathrm{OH} / \mathrm{NHCOCH} \mathrm{H}_{3}$ and $\mathrm{NH}_{2} / \mathrm{NH}_{2}$ aromatic bis-substitution are all extremely active, with $\mathrm{IC}_{50}$ values in nanomolar region, while the monosubstituted compounds (chart 1) are approximately an order of magnitude less potent. The toxicity profile on PC3 prostate cancer cells is remarkably similar to that found on MDA-MB-231 breast cancer cells. It is notable that $\mathbf{6 , 8}$, and 9 are much more effective against MDA-MB-231 and PC-3 cells than the ferrocenyl tamoxifen ${ }^{12}$ and nilutamide ${ }^{13}$ and testosterone complexes, ${ }^{14}$ respectively. Surprisingly, $\mathbf{5}$ is also quite active, even lacking aromatic substitution, further demonstrating the antiproliferative properties of the [3]ferrocenophane moiety.

However, a rather startling result was obtained; compound 7, possessing two amide groups shows an anomalously mild toxicity on both cell lines. With respect to the other disubstituted compounds, the behavior of this compound contradicts all our previous observations. Potential insolubility of $\mathbf{7}$ has been ruled out; its solubility in DMSO/water is similar to that of monosubstituted compound $\mathbf{3}$ and much better than that of unsubstituted compound 5. It should be mentioned, however, that esterases and amidases, ${ }^{15-18}$ which hydrolyze amides to amines, and arylamine $\mathrm{N}$-acetyltransferases, ${ }^{19-21}$ which convert amines to acetamides, theoretically allow the conversion between the two forms, and it is thus difficult to identify the active species in the cell. Considering that the diamino 9 is very active while the diamido $\mathbf{7}$ is almost inactive, and that the activities of amido compounds $\mathbf{3}$ and $\mathbf{8}$ are close to that of amino compounds $\mathbf{2}$ and $\mathbf{6}$, the hypothesis (currently under investigaton) of conversion of amide to amine in the cell media and that the amino form is the active species seems reasonable and the inactivity of the diamido 7 may be due to its inaccessibility to hydrolysis site of amidase.

In conclusion, we have found that the cytotoxic activity of ferrocenyl compounds based on the diphenylethylene structure can be markedly improved by the exchange of ferrocene for ferrocenophane and the substitution of both phenyl rings with protic groups. In particular, such compounds possessing $\mathrm{OH} / \mathrm{OH}, \mathrm{OH} / \mathrm{NH}_{2}, \mathrm{OH} / \mathrm{NHCOCH} \mathrm{H}_{3}$ and $\mathrm{NH}_{2} / \mathrm{NH}_{2}$ substitution are active in nanomolar concentrations, placing them among the most effective organometallic cancer drug candidates heretofore discovered. We have postulated in ferrocene series that quinone methides ${ }^{22,23}$ or imine methides ${ }^{6}$ could be active metabolites of these types of compounds, and this hypothesis remains consistent with the data reported here. 
Chimie ParisTech (Ecole Nationale Supérieure de Chimie de Paris), Laboratoire Charles Friedel, UMR CNRS 7223, 11 rue Pierre et Marie Curie, 75231 Paris Cedex 05, France. Fax: +331 432600 61; Tel: +331 442766 99; E-mail: : siden-top@ @himie-paristech.fr

Supporting information available. Synthetic procedures and characterization for 5-9. Crystallographic data (excluding structure factors) for $\mathbf{7}$ have been deposited with the Cambridge Crystallographic Data Centre as supplementary publication no. \#\#\#\#\#. Copies of the data can be obtained, free of charge, on application to CCDC, 12 Union Road, Cambridge CB2 1EZ, UK, (fax: +44-(0)1223-336033 or e-mail: deposit@ ccdc.cam.ac.uk).

Acknowledgements. We thank P. Herson for X-ray structural characterization as well as the Agence Nationale de la Recherche (No. ANR-06-BLAN-0384-01, "FerVect") financial support. M. G. acknowledges fellowship from the Ministère des Affaires Etrangères de la France.

\section{Notes and references}

1 D. Plazuk, A. Vessieres, E. A. Hillard, O. Buriez, E. Labbe, P. Pigeon, M. A. Plamont, C. Amatore, J. Zakrzewski and G. Jaouen, J. Med. Chem., 2009, 52, 4964-4967.

2 M. Gormen, P. Pigeon, E. A. Hillard, M. A. Plamont, D. Plażuk, S. Top, A. Vessières and G. Jaouen, Tetrahedron Lett., 2010, 51, 118-120.

3 T. D. Turbitt and W. E. Watts, J. Organometal. Chem., 1972, 46, 109-117.

4 J. Shani, A. Gazit, T. Livshitz and S. Biran, J. Med. Chem., 1985, 28, 1504-1511.

5 H. Dehmlow, J. D. Aebi, S. Jolidon, Y.-H. Ji, E. M. Von Mark, J. Himber and O. H. Morand, J. Med. Chem., 2003, 46, 3354-3370.

6 P. Pigeon, S. Top, O. Zekri, E. A. Hillard, A. Vessieres, M. A. Plamont, O. Buriez, E. Labbe, M. Huche, S. Boutamine, C. Amatore and G. Jaouen, J. Organomet. Chem., 2009, 694, 895-901.

7 J. E. McMurry, Chem. Rev., 1989, 89, 1513-1524.

8 X.-F. Duan, J. Zeng, J.-W Lü, Z.-B. Zhang. J. Org. Chem., 2006, 71, 9873-9876.

$9 \quad$ S. Kirkwood and P. H. Philips, J. Am. Chem. Soc., 1947, 69, 934-936.

10 Crystal data for 5: $\mathrm{C}_{26} \mathrm{H}_{22} \mathrm{Fe}, M=390.31$, orthorhombic, $a=5.8601(9), b=31.829(4)$, $c=40.783(4) \AA, V=7606.9(17) \AA^{3}, T=200 \mathrm{~K}$, space group Fdd2, $Z=16,16586$ reflections measured, 4545 unique $\left[R_{\text {int }}=0.001\right]$, the final $\mathrm{wR}\left(\mathrm{F}_{2}\right)$ was 0.0736 ; for Z8. $\mathrm{CH}_{3} \mathrm{CN}: \mathrm{C}_{30} \mathrm{H}_{28} \mathrm{FeN}_{2} \mathrm{O}_{2}, M=504.41$, monoclinic, $a=5.8841(7), b=19.872(2), c=$ 11.1212(17) $\AA, \beta=95.141(10)^{\circ}, V=1295.1(3) \AA^{3}, T=200 \mathrm{~K}$, space group $\mathrm{P} 2{ }_{1}, Z=2$, 21998. reflections measured, 3870 unique $\left[R_{\text {int }}=0.001\right]$, 9257, the final $\mathrm{wR}\left(\mathrm{F}_{2}\right)$ was 0.1068 .

11 P. Liptau, S. Knüppel, G. Kehr, O. Kataeva, R. Fröhlich and G. Erker, J. Organomet. Chem., 2001, 637-639, 621-630.

12 S. Top, A. Vessières, G. Leclercq, J. Quivy, J. Tang, J. Vaissermann, M. Huché and G. Jaouen, Chem. Eur. J., 2003, 9, 5223-5236.

13 O. Payen, S. Top, A. Vessières, E. Brulé, M.-A. Plamont, M. J. McGlinchey, H. Müller-Bunz, G. Jaouen, J. Med. Chem., 2008, 51, 1791-1799.

14 S. Top, C. Thibaudeau, A. Vessières, E. Brulé, F. Le Bideau, J.-M. Joerger, M.-A. Plamont, S. Samreth, A. Edgar , J. Marrot, P. Herson, G., Jaouen, Organometallics, 2009, 28, 1414-1424.

15 T. Bisogno, K. Katayama, D. Melck, N. Ueda, L.D. Petrocellis, S. Yamamoto, V.D. Marzo, Eur. J. Biochem., 1998, 254, 634.

16 J. Katz, M. Levitz, S. S. Kadner, T.H. Finlay, J. Steroid Biochem. Mol. Biol., 1991, 38, 17. 
17 J. Katz, T.H. Finlay, S. Banerjee, M. Levitz, J. Steroid Biochem., 1987, 26, 687.

18 J.V. Watson, S.H. Chambers, P. Workman, T.S. Horsnell, FEBS Lett., 1977, 81, 179.

19 J. Dairou, N. Atmane, F. Rodrigues-Lima, J.-M. Dupret, J. Biol. Chem., 2004, 279, 7708.

20 J.A. Williams, D.H. Phillips, Cancer Res., 2000, 60, 4667.

21 P. J. Adam, J. Berry, J. A. Loader, K. L. Tyson, G. Craggs, P. Smith, J. De Belin, G. Steers, F. Pezzella, K. F. Sachsenmeir, A. C. Stamps, A. Herath, E. Sim, M. J. O’Hare, A. L. Harris, J. A. Terrett, Mol. Cancer Res., 2003, 1, 826-835.

22 E. A. Hillard, A. Vessières, L. Thouin, G. Jaouen, C. Amatore, Angew. Chem. 2005, 118, 291; Angew. Chem. Int. Ed. 2006, 45, 285-290.

23 D. Hamels, P. M. Dansette, E. A. Hillard, S. Top, A. Vessières, P. Herson, G. Jaouen, D. Mansuy, Angew. Chem. Int. Ed. 2009, 48, 9124-9126. 